\title{
DETERMINAN KEPEMILIKAN JAMBAN SEHAT DI BAGAN DESA PERCUT
}

\author{
Rio Ferdi Yuandra ${ }^{1}$, Bella Anggreni S Pangestika \\ Fakultas Kesehatan Masyarakat \\ Institut Kesehatan Deli Husada Delitua \\ e-mail : rio.skm.mkm@gmail.com
}

\begin{abstract}
Healthy latrine ownership is one indicators of an ecological and healthy environment. According to WHO, it turns out $12.9 \%$ of Indonesia's population who do not have latrines, $2.4 \%$ billion of the world's population who do not have healthy latrines, with a ratio of seven from ten, mostly of them are river. In Indonesia, goose neck toilets are used $84.4 \%$, with a thickness of $4.8 \%$, with a floor of $3.7 \%$. The purpose of this study was to find out the relationship between Income, Knowledge, Attitudes, and Habits with Healthy Latrine Ownership at Bagan Percut Village in 2019. Research is conducted by using an analytical method with a cross-sectional design plan. The population of this study was the Head of Family at Bagan Percut Village as many as 624 peoples. The sample of this study was part of a population of 86 peoplesthat used simple random sampling. The results obtained by using the chi-Square test showed that there was a relationship between income, Knowledge, Attitudes, and Habits with Healthy Latrine Ownership. It is recommended that community officers to be more creative in providing health education with regarding to healthy latrines, for example by using a trigger method with used a tool in the form of transmission posters of diseases caused by human feces and did direct observations in places where people are used to defecation openly.
\end{abstract}

Keywords: Income, Knowledge, Attitudes, Habits.

\section{PENDAHULUAN}

Keadaan masa depan masyarakat Indonesia yang ingin dicapai melalui pembangunan kesehatan adalah masyarakat, bangsa dan negara yang ditandai oleh penduduknya yang hidup dalam lingkungan dan perilaku hidup sehat, baik jasmani, rohani maupun sosial. Lingkungan masyarakat merupakan salah satu variabel yang kerap mendapat perhatian khusus dalam menilai kondisi kesehatan masyarakat. Masalah penyehatan lingkungan khususnya pada pembuangan tinja merupakan salah satu dari berbagai masalah kesehatan yang perlu mendapatkan prioritas (Depkes RI, 2009).

Kesehatan merupakan suatu fenomena sosial, maka disadari bahwa pelayanan kesehatan bukanlah satu-satunya faktor yang berpengaruh terhadap kesehatan masyarakat, melainkan dipengaruhi juga oleh faktor perilaku dan lingkungan, yang berpengaruhnya jauh lebih besar. Salah satu faktor lingkungan yang sangat berpengaruh adalah penyediaan air bersih dan serta kebiasaan masyarakat yang suka buang air besar disembarang tempat (Eti Martina, 2016).

Masalah kesehatan adalah suatu masalah yang sangat kompleks, yang saling berkaitan dengan masalah-masalah lain diluar kesehatan itu sendiri. Demikian pula pemecahan masalah kesehatan masyarakat, tidak hanya dilihat dari segi kesehatannya sendiri, tapi harus dilihat dari seluruh segi yang ada pengaruhnya terhadap masalah "sehat-sakit" atau kesehatan tersebut.

Derajat kesehatan dipengaruhi oleh beberapa faktor yaitu lingkungan, perilaku, pelayanan medis, dan keturunan. Lingkungan merupakan faktor yang besar pengaruhnya terhadap kesehatan individu dan masyarakat. Keadaan lingkungan yang tidak memenuhi persyaratan kesehatan dan perilaku masyarakat dapat merugikan kesehatan baik masyarakat di pedesaan maupun perkotaan yang disebabkan 


\begin{tabular}{l|c|c}
\hline Jurnal Penelitian Kesmasy & Vol. 2 No. 1 & Edition: May - October 2019 \\
\hline & http://ejournal.delihusada.ac.id/index.php/JPKSY & \\
\cline { 2 - 3 } Received: 30 September 2019 & Revised: 09 October 2019 & Accepted: 18 October 2019
\end{tabular}

kurangnya pengetahuan dan kemampuan masyarakat dibidang kesehatan, ekonomi, maupun teknologi. Kondisi lingkungan yang berpengaruh terhadap kesehatan tersebut adalah penyediaan air bersih, penyediaan jamban sehat, kondisi rumah dan kondisi lingkungan permukiman (Ady, 2011).

Salah satu upaya penting untuk meningkatkan derajat kesehatan adalah pengadaan lingkungan fisik yang sehat bagi masyarakat jamban pada umumnya merupakan salah satu sarana yang diperlukan untuk mewujudkan lingkungan bersih dan sehat. Dengan tersedianya jamban yang memenuhi syarat kesehatan sehingga dapat terhindar dari penyebaran penyakit (Tarigan, 2008).

Buang air besar sembarangan merupakan salah satu permasalahan kesehatan di Indonesia untuk meningkatkan derajat kesehatan masyarakat dimana yang menjadi tantangannya adalah masalah sosial budaya. Budaya masyarakat lebih suka membuang air besar (BAB) di sembarangan tempat membuat mereka enggan membuat jamban di rumah masing-masing (Gandha, 2015).

Masalah penyakit lingkungan pemukiman khususnya pada pembuangan tinja terutama pelaksanannya tidaklah mudah, karena menyangkut peran serta masyarakat yang biasanya sangat erat kaitannya dengan perilaku, tingkat ekonomi, kebudayaan, dan pendidikan. Pembuangan tinja perlu mendapat perhatian khusus karena merupakan salah satu bahan buangan yang banyak mendatangkan masalah dalam bidang kesehatan dan sebagai media bibit penyakit. Selain itu dapat menimbulkan pencemaran lingkungan pada sumber air dan bau busuk serta estetika (Syaifuddin, 2000).

Berdasarkan data WHO pada tahun 2013 diperkirakan sebesar 1,1 milyar orang atau $17 \%$ penduduk dunia masih buang air besar di area terbuka, dari data tersebut diatas sebesar $81 \%$ penduduk yang Buang Air Besar Sembarangan (BABS) terdapat di 10 negara dan Indonesia sebagai negara kedua terbanyak ditemukan masyarakat buang air besar di area terbuka, yaitu India (58\%), Indonesia (12,9\%), China (4,5\%), Ethiopia (4,4\%), Pakistan (4,3\%), Nigeria (3\%), Sudan $(1,5 \%)$, Nepal $(1,3 \%)$, Brazil $(1,2 \%)$, dan
Nigeria (1,1\%) (WHO, 2014).

Menurut jenis tempat buang air besar yang digunakan, sebagian besar rumah tangga di Indonesia menggunakan kloset berjenis leher angsa sebesar $84,4 \%$, plengsengan sebesar 4,8\%, cemplung/cubluk/lubang tanpa lantai sebesar $7,2 \%$, dan cemplung/cubluk/lubang dengan lantai sebesar 3,7\%. Berdasarkan tempat pembuangan akhir tinja, hasil Riskesdas 2013 sebesar 66\% rumah tangga di Indonesia menggunakan tangki septik sebagai tempat pembuangan akhir tinja. Rumah tangga yang menggunakan tempat Saluran Pembuangan Akhir Limbah (SPAL) sebesar 4\%, kolam/sawah sebsar 4,4\%, sungai/danau/laut sebesar 13,9\%, lubang 4 tanah sebesar 8,6\%, pantai/tanah lapang/kebun sebesar 2,7\% (Depkes RI, 2013).

Mengutip dari CNN Indonesia tentang laporan Join Monitoring Program (JMP) WHO/Unicef, ternyata masih terdapat 12,9\% penduduk Indonesia yang belum memiliki jamban, dari 2,4 miliar penduduk dunia yang tidak memiliki jamban, dengan rasio tujuh dari sepuluh orang di dunia masih BAB ditempat terbuka, dimana sebagian besar adalah sungai. Di Indonesia, kloset leher angsa yang digunakan $84,4 \%$, plengsengan 4,8\%, cemplung dengan lantai 3,7\%.

Menurut survei pendahuluan yang dilakukan pada 13 Februari 2019 di Bagan Desa Percut Kecamatan Percut Sei Tuan Kabupaten Deli Serdang, diketahui bahwa di Bagan Desa Percut memiliki jumlah penduduk sebanyak 2.396 orang dengan jumlah Kepala Keluarga (KK) sebanyak 624 KK. Berdasarkan data yang diperoleh dari Pemerintah Kabupaten Deli Serdang Kecamatan Percut Sei Tuan Bagan Desa Percut tentang persentase kepemilikan jamban sehat sebanyak $70 \%$, dan sisanya $30 \%$ tidak memiliki jamban sehat.

Berdasarkan latar belakang diatas maka peneliti tertarik untuk melakukan penelitian apa saja yang menjadi deterninan kepemilikan jamban sehat di Bagan Desa Percut Kecamatan Percut Sei Tuan Kabupaten Deli.

\section{METODE PENELITIAN}

Jenis penelitian kuantitatif dengan desain cross secsional, dilaksanakan di Bagan Desa Percut Kecamatan Percut Sei Tuan Kabupaten Deli 


\begin{tabular}{l|c|c}
\hline Jurnal Penelitian Kesmasy & Vol. 2 No. 1 & Edition: May - October 2019 \\
\hline & http://ejournal.delihusada.ac.id/index.php/JPKSY & \\
\cline { 2 - 2 } Received: 30 September 2019 & Revised: 09 October 2019 & Accepted: 18 October 2019
\end{tabular}

Serdang Tahun 2019. Penelitian ini dilakukan mulai bulan Mei 2019. Populasi pada penelitian ini adalah Kepala keluarga dan sampel dalam penelitian ini adalah sebagian dari Kepala Keluarga yang ada di bagan Desa Percut Kecamatan Percut sei Tuan Kabupaten Deli Serdang. Teknik pengambilan sampel pada penelitian ini dilakukan secara acak sederhana atau simple random sampling, dimana setiap populasi mempunyai kesempatan yang sama untuk diambil menjadi sampel penelitian dengan jumlah 86 orang.

\section{HASIL DAN PEMBAHASAN}

\section{Hubungan Pendapatan Dengan Kepemilikan Jamban Sehat}

Berdasarkan hasil penelitian yang ditampilkan pada tabel 1 dapat dilihat bahwa responden dengan pendapatan tinggi mengenai kepemilikan jamban sehat sebanyak 20 orang $(23,3 \%)$ sudah memiliki jamban sehat dan responden dengan pendapatan tinggi mengenai kepemilikan jamban sehat tidak memiliki jamban sehat sebanyak 15 orang $(17,4 \%)$, sedangkan responden dengan pendapatan rendah mengenai kepemilikan jamban sehat sebanyak 12 orang $(14,0 \%)$ sudah memiliki jamban sehat dan responden dengan pendapatan rendah mengenai kepemilikan jamban sehat sebanyak 39 orang $(45,3 \%)$ tidak memiliki jamban sehat.

Tabel 1. Analisis Hubungan Pendapatan Dengan Kepemilikan Jamban Sehat

\begin{tabular}{|c|c|c|c|c|c|c|c|}
\hline \multirow{3}{*}{ Pendapatan } & \multicolumn{4}{|c|}{$\begin{array}{c}\text { Kepemilikan jamban } \\
\text { sehat }\end{array}$} & \multirow{2}{*}{\multicolumn{2}{|c|}{ Total }} & \multirow{3}{*}{$p$} \\
\hline & \multicolumn{2}{|c|}{ Memiliki } & \multicolumn{2}{|c|}{$\begin{array}{c}\text { Tidak } \\
\text { memiliki }\end{array}$} & & & \\
\hline & $\mathrm{n}$ & $\%$ & $\mathrm{n}$ & $\%$ & $\mathrm{n}$ & $\%$ & \\
\hline Tinggi & 20 & 23,3 & 15 & 17,4 & 35 & 40,7 & 0 \\
\hline Rendah & 12 & 14,0 & 39 & 45,3 & 51 & 59,3 & J,003 \\
\hline Total & 32 & 37,2 & 54 & 62,8 & 86 & 100 & \\
\hline
\end{tabular}

Dari hasil analisis antara pendapatan dengan kepemilikan jamban sehat yang menggunakan uji Chi-Squaremenunjukkan bahwa $\mathrm{p}=0,003$ $(p<0,05)$ Hal ini berarti terdapat hubungan yang signifikan antara hubungan Pendapatandengan Kepemilikan Jamban Sehat. Dilihat dari Prevalence Ratio 4,333 maka dapat di artikan bahwa pendapatan responden memiliki peluang 4 kali lebih besar dalam kepemilikan jamban sehat.

\section{Hubungan Pengetahuan dengan Kepemilikan Jamban Sehat}

Berdasarkan tabel 2 dapat dilihat bahwa responden dengan pengetahuan baik mengenai kepemilikan jamban sehat sebanyak 19 orang $(22,1 \%)$ yang memiliki jamban sehat dan responden dengan pengetahuan baik mengenai kepemilikan jamban sehat yang tidak memiliki jamban sehat sebanyak 15 orang $(17,4 \%)$, sedangkan responden dengan pengetahuan buruk mengenai kepemilikan jamban sehat sebanyak 13 orang $(15,1 \%)$ yang memiliki jamban sehat dan responden dengan pengetahuan buruk mengenai kepemilikan jamban sehat sebanyak 39 orang $(45,4 \%)$ yang tidak memiliki jamban sehat.

Tabel 2. Hubungan Pengetahuan dengan Kepemilikan Jamban Sehat

\begin{tabular}{|c|c|c|c|c|c|c|c|}
\hline \multirow{3}{*}{ Pengetahuan } & \multicolumn{4}{|c|}{$\begin{array}{c}\text { Kepemilikan jamban } \\
\text { sehat }\end{array}$} & \multirow{2}{*}{\multicolumn{2}{|c|}{ Total }} & \multirow{3}{*}{$p$} \\
\hline & \multicolumn{2}{|c|}{ Memiliki } & \multicolumn{2}{|c|}{$\begin{array}{c}\text { Tidak } \\
\text { memiliki }\end{array}$} & & & \\
\hline & $n$ & $\%$ & $n$ & $\%$ & $\mathrm{n}$ & $\%$ & \\
\hline Baik & 19 & 22,1 & 15 & 17,4 & 32 & 39,5 & \\
\hline Buruk & 13 & 15,1 & 39 & 45,4 & 54 & 60,5 & 0,008 \\
\hline Total & 32 & 37,2 & 54 & 62,8 & 86 & 100 & \\
\hline
\end{tabular}

Dari hasil analisis antara pengetahuan dengan kepemilikan jamban sehat yang menggunakan uji Chi-Squaremenunjukkan bahwa $\mathrm{p}=0,008$ $(p<0,05) \quad$ Hal ini berarti terdapat hubungan yang signifikan antara hubungan Pengetahuandengan Kepemilikan Jamban Sehat. Dilihat dari Prevalence Ratio 3,800 maka dapat di artikan bahwa pengetahuan responden memiliki peluang 4 kali lebih besar dalam kepemilikan jamban sehat.

\section{Hubungan Sikap dengan Kepemilikan Jamban Sehat}

Berdasarkan tabel 3 dapat dilihat bahwa responden dengan sikap baik mengenai kepemilikan jamban sehat sebanyak 18 orang $(20,9 \%)$ yang memiliki jamban sehat, sedangkan responden dengan sikap baik mengenai kepemilikan jamban sehat yang tidak memiliki jamban sehat sebanyak 13 orang $(15,1 \%)$, dan responden dengan sikap buruk mengenai kepemilikan jamban sehat sebanyak 14 orang $(16,3 \%)$ yang memiliki jamban sehat dan 
responden dengan sikap buruk mengenai kepemilikan jamban sehat sebanyak 41 orang $(47,7 \%)$ yang tidak memiliki jamban sehat.

Tabel 3. Hubungan Sikap dengan Kepemilikan Jamban Sehat

\begin{tabular}{|c|c|c|c|c|c|c|c|}
\hline \multirow{3}{*}{ Sikap } & \multicolumn{4}{|c|}{$\begin{array}{c}\text { Kepemilikan jamban } \\
\text { sehat }\end{array}$} & \multirow{2}{*}{\multicolumn{2}{|c|}{ Total }} & \multirow{3}{*}{$p$} \\
\hline & \multicolumn{2}{|c|}{ Memiliki } & \multicolumn{2}{|c|}{$\begin{array}{c}\text { Tidak } \\
\text { memiliki }\end{array}$} & & & \\
\hline & $\mathrm{n}$ & $\%$ & $n$ & $\%$ & $n$ & $\%$ & \\
\hline Baik & 18 & 20,9 & 13 & 15,1 & 31 & 36,0 & $0 \Omega 0$ \\
\hline Buruk & 14 & 16,3 & 41 & 47,7 & 55 & 64,0 & 0,000 \\
\hline Total & 32 & 37,2 & 54 & 62,8 & 86 & 100 & \\
\hline
\end{tabular}

Dari hasil analisis antara sikap dengan kepemilikan jamban sehat yang menggunakan uji Chi-Square menunjukkan bahwa $\mathrm{p}=0,006$ $(p<0,05)$. Hal ini berarti terdapat hubungan yang signifikan antara hubungan Sikapdengan Kepemilikan Jamban Sehat. Dilihat dari Prevalence Ratio 4,055 maka dapat di artikan bahwa sikap responden memiliki peluang 4 kali lebih besar dalam kepemilikan jamban sehat.

\section{Hubungan Kebiasaan dengan Kepemilikan Jamban Sehat}

Berdasarkan tabel diatas dapat dilihat bahwa responden dengan kebiasaan baik mengenai kepemilikan jamban sehat sebanyak 21 orang $(24,4 \%)$ yang memiliki jamban sehat, sedangkan responden dengan kebiasaan baik mengenai kepemilikan jamban sehat yang tidak memiliki jamban sehat sebanyak 15 orang $(17,4 \%)$, dan responden dengan kebiasaan buruk mengenai kepemilikan jamban sehat sebanyak 11 orang $(12,8 \%)$ yang memiliki jamban sehat dan responden dengan kebiasaan buruk mengenai kepemilikan jamban sehat sebanyak 39 orang $(45,3 \%)$ yang tidak memiliki jamban sehat.

Tabel 4. Hubungan Kebiasaan dengan Kepemilikan Jamban Sehat

\begin{tabular}{|c|c|c|c|c|c|c|c|}
\hline \multirow{3}{*}{ Kebiasaan } & \multicolumn{4}{|c|}{$\begin{array}{c}\text { Kepemilikan jamban } \\
\text { sehat }\end{array}$} & \multirow{2}{*}{\multicolumn{2}{|c|}{ Total }} & \multirow{3}{*}{$p$} \\
\hline & \multicolumn{2}{|c|}{ Memiliki } & \multicolumn{2}{|c|}{$\begin{array}{c}\text { Tidak } \\
\text { memiliki }\end{array}$} & & & \\
\hline & $\mathrm{n}$ & $\%$ & $n$ & $\%$ & $\mathrm{n}$ & $\%$ & \\
\hline Baik & 21 & 24,4 & 15 & 17,4 & 36 & 41,9 & \\
\hline Buruk & 11 & 12,8 & 39 & 45,3 & 50 & 58,1 & 0,001 \\
\hline Total & 32 & 37,2 & 54 & 62,8 & 86 & 100 & \\
\hline
\end{tabular}

Dari hasil analisis antara kebiasaan dengan kepemilikan jamban sehat yang menggunakan uji Chi-Square menunjukkan bahwa $\mathrm{p}=0,001$ $(p<0,05)$. Hal ini berarti terdapat hubungan yang signifikan antara hubungan Kebiasaandengan Kepemilikan Jamban Sehat. Dilihat dari Prevalence Ratio 4,964 maka dapat di artikan bahwa pendapatan responden memiliki peluang 5 kali lebih besar dalam kepemilikan jamban sehat.

\section{KESIMPULAN}

Berdasarkan penelitian yang telah dilakukan oleh peneliti dengan menggunakan analisa chisquare tentang Faktor Yang Berhubungan Dengan Kepemilikan Jamban Sehat Di Bagan Desa Percut Kecamatan Percut Sei Tuan Kabupaten Deli Serdang Tahun 2019 dengan jumlah responden 86 orang dapat diambil kesimpulan sebagai berikut :

1. Terdapat hubungan yang signifikan antara Pendapatan dengan Kepemilikan Jamban Sehat dengan nilai $(p=0,003 ; p<0,05)$.

2. Terdapat hubungan yang signifikan antara Pengetahuan Dengan Kepemilikan Jamban Sehat dengan nilai $(p=0,008 ; p<0,05)$

3. Terdapat hubungan yang signifikan antara Sikap Dengan Kepemilikan Jamban Sehat dengan nilai $(p=0,006 ; p<0,05)$

4. Terdapat hubungan yang signifikan antara Kebiasaan Dengan Kepemilikan Jamban Sehat dengan nilai $(p=0,001 ; p<0,05)$.

\section{DAFTAR PUSTAKA}

Ady, 2011. Faktor-Faktor yang Mempengaruhi Kepemilikan Jamban Sehat.

Asmanur, 2014. Faktor-Faktor Yang Berhubungan Dengan Kepemilikan Jamban di Kelurahan Labalawa. Skripsi.

Darsana, I Nengah. 2014. Faktor Yang Berhubungan Dengan Kepemilikan Jamban Keluarga Di Desa Jehem Kecamatan Tembuku Kabupaten Bangli.Jurnal Kesehatan Lingkungan. Denpasar: Poltekes.

Martina, E.2016. Faktor-Faktor Yang Berhubungan Dengan Kepemilikan Jamban Sehat di Desa Napalakura Kecamatan Napabalano Kabupaten Muna

Novitry, Fera.2017. Determinan Kepemilikan Jamban Sehat di Desa Sukomulyo Martapura 


\begin{tabular}{|c|c|c|}
\hline Jurnal Penelitian Kesmasy & Vol. 2 No. 1 & Edition: May - October 2019 \\
\hline & http://ejournal.delihusada.ac.id/index.php/JPKSY & \\
\hline Received: 30 September 2019 & Revised: 09 October 2019 & Accepted: 18 October 2019 \\
\hline \multicolumn{3}{|c|}{ Palembang. Jurnal Ilmu Kesehatan. Program } \\
\hline \multicolumn{3}{|c|}{$\begin{array}{l}\text { Studi Kesehatan Masyarakat STIKES Al- } \\
\text { Maárif Baturaja. }\end{array}$} \\
\hline \multirow{2}{*}{\multicolumn{3}{|c|}{$\begin{array}{c}\text { Novianti, Assi. 2017. } \\
\text { Individu dengan } \\
\text { Keluarga } \text { Kepemilikan Jamban } \\
\text { Desa Aek Goti Kecamatan }\end{array}$}} \\
\hline & & \\
\hline \multicolumn{3}{|c|}{ Silangkitang Kabupaten Labuhan Batu } \\
\hline \multicolumn{3}{|c|}{ Selatan. Skripsi. Fakultas Kesehatan } \\
\hline \multicolumn{3}{|c|}{$\begin{array}{l}\text { Masyarakat Universitas Sumatera Utara } \\
\text { Medan. }\end{array}$} \\
\hline \multicolumn{3}{|c|}{$\begin{array}{r}\text { Pulungan, Aminah Arfah.2013.Faktor-Faktor Yang } \\
\text { Berhubungan Dengan Kepemilikan Jamban }\end{array}$} \\
\hline \multicolumn{3}{|c|}{ Keluarga Di Desa Sipange Julu Kecamatan } \\
\hline \multicolumn{3}{|c|}{$\begin{array}{l}\text { Sayur Matinggi Kabupaten Tapanuli Selatan. } \\
\text { Medan: Program Sajrana Fakultas Kesehatan }\end{array}$} \\
\hline \multicolumn{3}{|c|}{$\begin{array}{l}\text { Masyarakat Universitas Sumatera Utara } \\
\text { Departemen Kesehatan Lingkungan. }\end{array}$} \\
\hline
\end{tabular}

Putra, Ganda Sunaryo. 2017. Faktor-Faktor Yang Berhubungan dengan Kepemilikan Jamban Sehat di Desa Empakan Kecamatan Kayan Hulu. Pontianak: Universitas Muhammadiyah.

Widyastutik, Otik. 2016. Faktor Yang Berhubungan Dengan Kepemilikan Jamban Sehat Di Desa Malikian Kalimantan Barat. Pontianak: Fakultas Ilmu Kesehatan, Universitas Muhammadiyah.

Woodford, B.S. Josep, dkk. 2014. Faktor Yang Berhubungan Dengan Tersedianya Jamban Keluarga Sehat Di Desa Tompaso Dua Kecamatan Tompaso Barat Kabupaten Minahasa. 